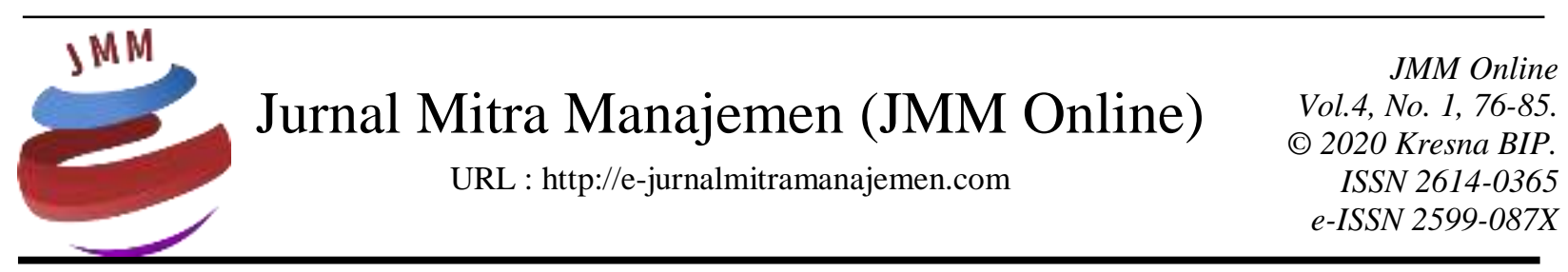

\title{
ANALISIS JANUARY EFFECT TERHADAP INDEKS HARGA SAHAM GABUNGAN DI BURSA EFEK INDONESIA PERIODE 2015-2019
}

\author{
Firrisa Tsamara Munica ${ }^{1)}$, Irni Yunita ${ }^{2)}$ \\ Universitas Telkom
}

\section{INFORMASI ARTIKEL}

Dikirim : 10 Januari 2020

Revisi pertama : 14 Januari 2020

Diterima : 17 Januari 2020

Tersedia online : 31 Januari 2020

Kata Kunci : Efek Januari, Return, IHSG

Email : risamunica@gmail.com

\section{ABSTRAK}

January effect adalah kondisi dimana return saham bulan Januari lebih tinggi dari rata-rata return bulan selain Januari. Tujuan dari penelitian ini adalah untuk mengetahui apakah terjadi January effect di Bursa Efek Indonesia atau tidak terjadi. Jika ada perbedaan return saham bulan Januari dengan rata-rata return bulan selain januari maka terjadi January effect, begitu pula sebaliknya. Data yang digunakan dalam penelitian ini adalah data sekunder. Penelitian ini menggunakan sampel seluruh perusahaan yang terdaftar di Bursa Efek Indonesia periode 2015-2019 dengan menggunakan data Indeks Harga Saham Gabungan (IHSG). Analisis data yang digunakan dalam penelitian ini adalah Uji One way ANOVA. Hasil dari analisis data yang telah dilakukan menunjukkan bahwa tidak terdapat perbedaan return saham pada bulan Januari dengan rata-rata return saham selain bulan Januari di Bursa Efek Indonesia periode 2015-2019, sehingga dapat disimpulkan bahwa di Bursa Efek Indonesia Periode 2015-2019 tidak terjadi January effect. 


\section{PENDAHULUAN \\ Latar Belakang}

Dalam pasar modal, sarana yang sangat diminati investor untuk berinvestasi adalah saham. Saham sangat diminati karena tingkat pengembalian saham lebih menarik di banding investasi keuangan lainnya. Saham adalah surat berharga yang dikeluargan perusahaan yang berbentuk Perseroan Terbatas (PT) atau yang biasa disebut emiten (Sunariyah 2011).

Ketika yang diinvestasikan adalah saham, maka yang dilihat oleh investor adalah return saham. Return adalah keuntungan yang diperoleh oleh perusahaan, individu, dan institusi dari hasil kebijakan investasi yang dilakukannya. Pengertian menurut Jogiyanto (2013:235) return merupakan hasil yang diperoleh dari investasi.

Saham dan return saham berpengaruh pada pasar modal yang baik. Pasar modal yang baik adalah pasar modal yang efisisen. Pasar modal dikatakan efisien ketika harga sekuritas telah mencerminkan informasi yang tersedia secara keseluruhan. Teori pasar modal efisien ini dicetuskan pertama kali oleh Fama pada tahun 1970. Fama (1970) dalam Jogiyanto (2013:548) menjelaskan bahwa teori tersebut terdapat tiga tingkatan, yaitu strong form, semi strong form, dan weak form. Tetapi dalam pasar efisien juga bisa terjadi penyimpangan yang dinamakan anomali pasar.

Pasar modal dapat dikatakan tidak efisien ketika suatu sekuritas bereaksi atas sesuatu hal diluar konsep yang ada dalam pasar efisien yang disebut juga sebagai gangguan atau anomali pasar. Ada beberapa bentuk anomali yang dapat menganggu efektifitas pasar modal. Menurut Levy (1996) dalam Alteza (2007), ia mengklasifikasikan anomali pasar menjadi empat jenis berdasarkan karakteristik event atau peristiwanya yaitu (1) anomali perusahaan (firm anomaly), anomali musiman (seasonal anomaly), anomali peristiwa (event anomaly), dan anomali akuntansi (accounting anomaly). Dalam anomali musiman salah satunya adalah adanya January effect.

January effect merupakan salah satu anomali pasar yang bertentangan dengan pasar modal yang efisien. January efect adalah kondisi dimana rata-rata return-nya cenderung lebih tinggi dibandingkan dengan bulan-bulan lainnya (Fitriyani, 2013). Dari pergerakan harga yang dapat di akses dari yahoo finance, dapat dilihat pada grafik dibawah ini bahwa lima tahun kebelakang memang dari bulan Desember ke bulan Januari selalu terjadi kenaikan, kecuali pada Desember 2016 ke Januari 2017 terjadi penurunan. Kenaikan harga penutupan IHSG dari bulan Desember ke Januari belum bisa membuktikan apakah hal tersebut yang dikatakan January effect atau tidak. 


\section{Gambar 1. Harga Penutupan IHSG Desember-Januari Tahun 2014-2019}

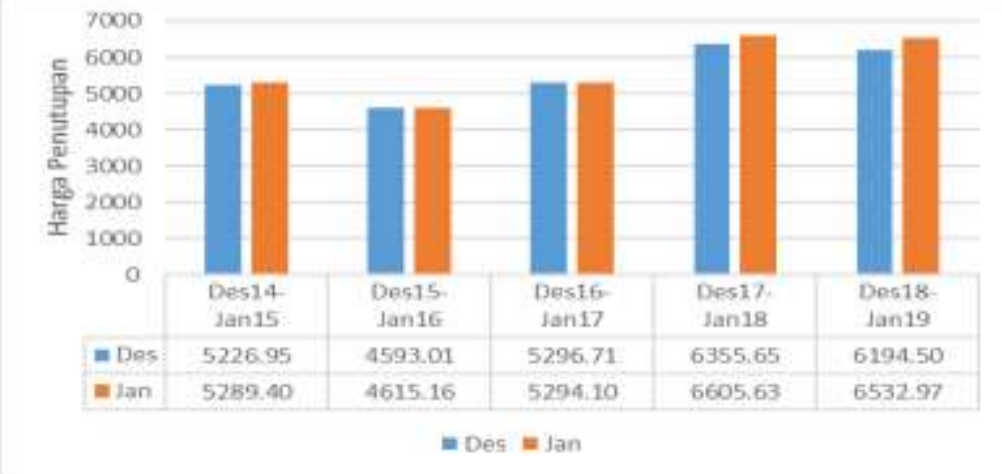

Sumber: Yahoo Finance (data diolah 2019)

Pada pasar modal Indonesia juga membuktikan return saham yang positif pada Indeks Harga Saham Gabungan (IHSG) sepanjang 2015-2019 saat bulan Januari, kecuali pada tahun 2017. Dalam lima tahun tersebut hanya pada tahun 2017 saja IHSG pada bulan Januari mengalami return yang negatif, yaitu $0,05 \%$ dalam MoM. IHSG merupakan nilai rata-rata saham dari perusahaan yang terdaftar di Bursa Efek Indonesia yang mempunyai return paling tinggi.

\section{Gambar 2. Return Saham IHSG Bulan Januari Tahun 2015-2019}

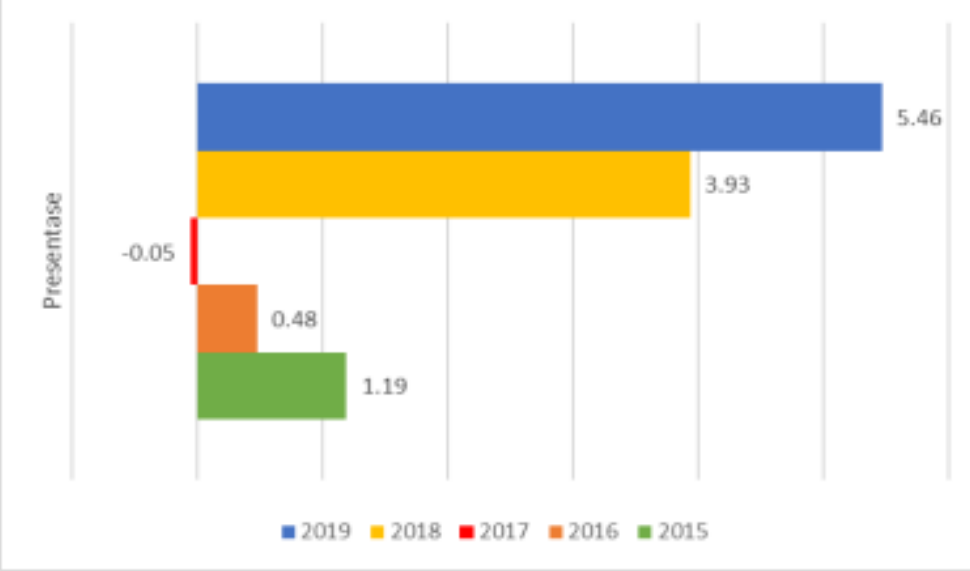

Sumber: Yahoo Finance (data diolah 2019)

Pada penelitian terdahulu beberapa peneliti menyatakan tidak terjadi January effect di Indonesia. Penelitian dari Dwi Cahyaningdyah dan Dhany Kurniawan (2013) menyatakan bahwa tidak terjadi January effect di Bursa Efek Indonesia periode 20112012. Penelitian yang dilakukan Fitri Aprilia \& Eka Ardhani (2014) menyatakan bahwa tidak terjadi January effect pada pasar modal Indonesia pada tahun 2012. Kemudian penelitian dari Sheryl Kadir dan Suramaya Suci (2014) menyatakan bahwa tidak terjadi fenomena January effect pada perusahaan yang terdaftar di LQ 45 di Bursa Efek Indonesia pada tahun 2010-2013. Peneliti lainnya, Mellina Audina dan Kazia Laturette (2017) juga menyatakan bahwa tidak terjadii January effect pada sektor property, real estate, dan building construction di BEI periode 2014-2016.

Namun beberapa peneliti terdahulu mempunyai hasil yang berbeda. Seperti Indah Fitriyani dan Maria M. Ratna Sari (2013) juga menyatakan bahwa terjadi January effect pada saham indeks LQ45 BEI periode 2009-2011. Penelitian dari Yoga 
(2010) menyatakan bahwa terjadi fenomena January effect pada indeks sektoral Bursa Efek Indonesia untuk Sektor Konsumsi. Peneliti lainnya, I Gusti Ayu Made Agung Mas Adriani Pratiwi, dkk. (2018) menyatakan bahwa fenimena January effect benar terjadi khususnya pada erusahaan BUMN di Bursa Efek Indonesia pada bulan Februari 2017 sampai dengan bulan Januari 2018.

\section{Rumusan Masalah}

Berdasarkan latar belakang diatas, maka rumusan masalah dalam penelitian ini adalah apakah terjadi January Effect pada Indeks Harga Saham Gabungan di Bursa Efek Indonesia Periode 2015-2019?.

\section{Tujuan Penelitian}

Berdasarkan rumusan masalah diatas, maka tujuan dalam penelitian ini adalah untuk mengetahui apakah terjadi January Effect pada Indeks Harga Saham Gabungan di Bursa Efek Indonesia Periode 2015-2019.

\section{KAJIAN PUSTAKA \\ Saham}

Dalam pasar modal, sarana yang sangat diminati investor untuk berinvestasi adalah saham. Saham sangat diminati karena tingkat pengembalian saham lebih menarik di banding investasi keuangan lainnya. Saham adalah surat berharga yang dikeluargan perusahaan yang berbentuk Perseroan Terbatas (PT) atau yang biasa disebut emiten (Sunariyah 2011). Pengertian saham lainnya menurut Sheryl dan Suramaya (2014), saham adalah tanda penyertaan modal seseorang atau suatu badan usaha ke dalam suatu perusahaan atau Perseroan Terbatas. Pihak yang melakukan penyertaan modal memiliki klaim atas pendapatan perusahaan, aset perusahaan dan berhak hadir dalam rapat umum pemegang saham (RUPS).

\section{Return Saham}

Return adalah keuntungan yang diperoleh oleh perusahaan, individu, dan institusi dari hasil kebijakan investasi yang dilakukannya. Pengertian menurut Jogiyanto (2013:235) return merupakan hasil yang diperoleh dari investasi. Terdapat dua jenis return, yaitu return realisasian (realized reutrn) dan return ekspektasi (expected return). Return realisasian merupakan return yang telah terjadi. Return realisasian dihitung menggunakan data historis. Return realisasian ini juga berguna sebagai dasar penentuan return ekspektasian. Sedangkan return ekspektasian adalah return yang diharapkan akan diperoleh oleh investor dimasa mendatang. Return ekspektasian sifatnya belum terjadi. Return ekspektasian sama denngan return pasar modal. Berarti, di Indonesia, return ekspektasian adalah return dari IHSG.

Return yang akan digunakan adalah return realisasian. Return realisasian yang akan dihitung adalah capital gain/capital loss yaitu selisih antara harga saham periode saat ini dengan harga saham pada periode sebelumnya. Rumus return saham (Jogiyanto, 2013) adalah : 


$$
R_{i t}=\frac{P_{i t}-P_{i t-1}}{P_{i t-1}}
$$

Keterangan:

$\mathrm{R}_{\mathrm{it}} \quad=$ Return saham i pada periode $\mathrm{t}$

$\mathrm{P}_{\mathrm{it}} \quad=$ Harga saham $\mathrm{i}$ pada periode $\mathrm{t}$

$\mathrm{P}_{\mathrm{it}-1} \quad=$ Harga saham $\mathrm{i}$ pada periode $\mathrm{t}-1$

\section{Efisiensi Pasar}

Efisiensi pasar dalam konteks ini adalah pasar modal dan pasar uang. Efisiensi pasar yang didefinisikan oleh Beaver (1989) dalam Jogiyanto (2013:558) adalah hubungan antara harga-harga sekuritas dengan informasi. Menurut Tandelilin (2017:224), pasar yang efisien adalah pasar dimana harga semua sekuritas yang diperdagangkan telah mencerminkan semua informasi yang tersedia. Informasi relevan yang tersedia seperti laba perusahaan di masa lalu atau bisa juga informasi mengenai rencana kenaikan dividen tahun ini. Pada intinya, pasar efisien adalah kondisi saat informasi tentang semua harga dapat diperoleh secara terbuka tanpa ada hambatan.

Ada beberapa kondisi yang harus terpenuhi untuk tercapainya pasar yang efisien. 1) Ada banyak investor yang rasional dan berusaha untuk memaksimalkan profit. 2) Semua pelaku pasar dapat memperoleh informasi pada saat yang sama dengan cara yang murah dan mudah. 3) Informasi yang terjadi bersifat acak. 4) Investor bereaksi secara cepat terhadap informasi baru, sehingga harga sekuritas akan berubah sesuai dengan perubahan nilai sebenarnya akibat informasi tersebut (Tandelilin, 2017:225).

Dalam rangka memudahkan penelitian tentang efisiensi pasar, Fama (1970) dalam Tandelilin (2017:227) mengklasifikasikan bentuk pasar yang efisien kedalam tiga efficient market hypothesis (EMH) yaitu, 1) Efisien dalam bentuk lemah (weak form), artinya pasar dimana harga sekuritas saat ini mencerminkan semua informasi masa lalu. Implikasi pada pasar efisien dalam bentuk lemah adalah investor tidak akan bisa memprediksi nilai pasar saham di masa datang dengan menggunakan data historis. 2) Efisien dalam bentuk setengah kuat (semi strong), artinya pasar dimana harga sekuritas saat ini mencerminkan semua informasi masa lalu dan informasi yang di publikasikan saat ini. Implikasi pada pasar efisien dalam bentuk setengah kuat adalah investor tidak akan bisa memprediksi nilai pasar saham di masa datang dengan menggunakan data yang dipublikasikan. 3) Efisiensi dalam bentuk kuat (strong form), artinya pasar dimana harga sekuritas saat ini mencerminkan semua informasi yang ada baik informasi dari masa lalu, informasi yang dipublikasikan saat ini, maupun informasi yang tidak terpublikasi.

\section{Anomali Pasar}

Anomali pasar merupakan kondisi dimana terdapat hal-hal yang tidak seharusnya ada atau menyimpang dari pasar yang efisien. Menurut kamus besar Bahasa Indonesia (KBBI), anomali pasar adalah suatu keadaan yang menyimpang yang terjadi dalam pasar. Adanya anomali pasar ini membuat para investor harus 
berhati-hati dengan pengambilan keputusan untuk berinvestasi. Menurut Gumanti (2011:343), dalam teori keuangan di kenal empat macam anomali pasar, yaitu:

1. Anomali peristiwa

a. Analysts' recommendation anomaly, yaitu semakin banyak analis merekomendasi untuk membeli suatu saham, semakin tinggi peluang harga akan turun

b. Insider trading anomaly, yaitu semakin banyak saham yang dibeli oleh insiders, semakin tinggi kemungkinan harga akan naik

c. Listings anomaly, yaitu harga sekuritas cenderung naik setelah perusahaan mengumumkan akan melakukan pencatatan saham di bursa

d. Value line/rating changes anomaly, yaitu harga sekuritas akan terus naik setelah value line menempatkan rating perusahaan pada urutan tinggi

2. Anomali musiman

a. January effect, yaitu harga sekuritas cenderung naik di bulan Januari, khususnya di hari-hari pertama

b. Week-end effect, yaitu harga sekuritas cenderung naik hari Jumat

c. Seasonal effect, yaitu saham perusahaan dengan penjualan musiman tinggi cenderung naik selama musim ramai

d. Holidays effect, yaitu ditemukan return positif pada hari terakhir sebelum liburan

e. Anomali perusahaan

3. Size anomaly, yaitu return pada perusahaan kecil cenderung lebih besar walaupun sudah disesuaikan dengan risiko

a. Closed-end mutual funds, yaitu return pada close-end funds yang dijual dengan potongan cenderung lebih tinggi

b. Neglect, yaitu perusahaan yang tidak diikuti oleh banyak analis cenderung menghasilkan return lebih tinggi

c. Institutional holdings, yaitu perusahaan yang dimiliki oleh sedikit institusi cenderung memiliki return lebih tinggi

4. Anomali akuntansi

a. Price earnings ratio anomaly, yaitu saham dengan $\mathrm{P} / \mathrm{E}$ ratio rendah cenderung memiliki return yang lebih tinggi

b. Earnings surprise, yaitu saham dengan capaian earnings lebih tinggi dari yang diperkirakan cenderung mengalami peningkatan harga

c. Price to sales anomaly, yaitu jika rasionya rendah cenderung memiliki kinerja lebih baik

d. Price to book anomaly, yaitu jika rasionya rendah cenderung berkinerja lebih baik

e. Dividend yield anomaly, yaitu jika yield-nya tinggi cenderung berkinerja lebih baik

f. Earnings momentum anomaly, yaitu saham perusahaan yang tingkat pertumbuhan earnings-nya meningkat cenderung berkinerja lebih baik. 


\section{January Effect}

January effect merupakan salah satu anomali pasar yang bertentangan dengan pasar yang efisien. January efect adalah kondisi dimana rata-rata return-nya cenderung lebih tinggi dibandingkan dengan bulan-bulan lainnya. January effect pertama kali diperkenalkan oleh Wachtel pada tahun 1942 namun baru mendapatkan perhatian setelah Rozzeff dan Kinney melakukan penelitian di tahun 1976, penelitian tersebut menunjukkan perbedaan keadaan yang cukup jelas di bulan Januari, terutama di minggu-minggu awal (Fitriyani, 2013).

Menurut Wachtel (1942) dalam Audina (2017) beberapa faktor yang memperngaruhi January effect yaitu, 1) Adanya pengaruh pembayaran pajak pada akhir tahun. Dimana mayoritas investor memiliki kecenderungan menjual saham yang memiliki return kurang bagus sehingga dapat mengurangi jumlah pembayaran pajak. Hal ini menyebabkan harga saham menurun. 2) Adanya permintaan uang tunai yang melebihi ratarata pada minggu pertama atau minggu kedua sebelum Natal setiap tahunnya, yang menyebabkan banyak saham yang dijual pada pasar modal sehingga harga saham menurun. 3) Adanya kecenderungan harga saham naik pada hari sebelum setiap liburan yakni 24 Desember dan 31 Desember, dimana investor membeli saham yang jatuh semenjak pertengahan Desember. 4) Adanya kepercayaan bahwa tahun baru akan lebih baik dari tahun sebelumnya. Selain itu menurut Zacks (2012:26) dalam Audina (2017), faktor-faktor yang menyebabkan January effect adalah sebagai berikut: a. Tax loss selling

Tax loss selling membuat pasar tidak bergerak sesuai informasi yang ada. Investor tidak menjual saham berdasarkan informasi yang ada di pasar, namun menjualnya dalam rangka keperluan pribadi yakni memanfaatkan return saham yang memiliki performa kurang bagus atau dengan kata lain merugi dengan menjualnya untuk mengurangi pembayaran pajak.

b. Window dressing

Window dressing menyebabkan harga pasar anjlok pada akhir tahun. Anjloknya harga saham pada akhir tahun akan menarik invetor untuk membelinya sehingga harga saham pada awal tahun akan melambung tinggi.

c. Small stocks

Faktor small stock berkaitan dengan tax loss selling. Dimana pada akhir tahun investor yang memiliki small stocks akan memilih untuk menjual saham ini dengan posisi rugi dalam rangka mengakui kerugian untuk mengurangi pembayaran pajak. Small stocks jarang diperdagangkan, sehingga bila investor ingin mengakui kerugian, maka harga saham menjadi overly depressed. Hal ini menyebabkan small stock yang memiliki performa tidak bagus pada akhir tahun akan melambung tinggi pada bulan Januari.

\section{METODE PENELITIAN \\ Jenis Penelitian}

Pada penelitian ini, metode yang digunakan adalah metode kuantitatif. Data yang digunakan dalam penelitian ini adalah data berupa angka atau yang bisa dihitung menggunakan nominal. Metode kuantitatif menurut Sugiyono (2016:8) adalah metode penelitian yang berlandaskan filsafat positivisme, digunakan untuk meneliti pada 
populasi atau sampel tertentu, pengumpulan data menggunakan instrumen penelitian, analisis data bersifat kuantitatif atau statistik, dengan tujuan untuk menguji hipotesis yang telah ditetapkan.

Penelitian ini menggunakan data sekunder, sehingga data seperti harga saham, laporan tahunan, dan return didapatkan dari website resmi Bursa Efek Indonesia atau yahoo finance dengan objek Indeks Harga Saham Gabungan periode 2015 - 2018. Waktu yang digunakan untuk menyelesaikan penelitian ini dilakukan dalam jangka waktu 5 bulan dimulai dari September 2019 - Januari 2020. Periode penelitian yang digunakan untuk menganalisis January effect pada IHSG Bursa Efek Indonesia yaitu pada periode 2015-2019.

\section{Teknik Pengumpulan Data}

Data yang digunakan dalam penelitian ini merupakan data sekunder yang didapatkan dari idx.co.id dan yahoo finance. Populasi penelitian ini adalah return Indeks Harga Saham Gabungan tahun 2015-2019. Sampel yang digunakan adalah seluruh perusahaan yang terdaftar di Bursa Efek Indonesia periode 2015-2019 dengan menggunakan data Indeks Harga Saham Gabungan (IHSG). Terdapat 5 bulan Januari dan 55 bulan selain Januari pada periode 2015-2019 untuk membuktikan January Effect.

\section{HASIL PENELITIAN DAN PEMBAHASAN}

Dari pengujian normalitas, data yang digunakan terdistribusi normal yang artinya data dapat dilanjutkan untuk uji homogenitas dan uji one way ANOVA. Dalam hasil uji hemogenitas membuktikan bahwa data dalam penelitian ini memiliki variansi yang sama, tidak berasal dari kelompok yang berbeda. Hasil uji one way ANOVA adalah sebagai berikut:

Tabel 1. Hasil Uji One Way ANOVA

\begin{tabular}{|c|c|c|c|c|c|}
\hline & & ANOVA & & & \\
\hline Retum & & & & & \\
\hline & Sum of Squares & df & Mean Square & $\mathrm{F}$ & Sig. \\
\hline Between Groups & .005 & 1 & .005 & 4.115 & .077 \\
\hline Within Groups & .009 & 8 & .001 & & \\
\hline Total & .014 & 9 & & & \\
\hline
\end{tabular}

Sumber : Hasil Penelitian, diolah (2019)

Dari tabel diatas yang menunjukkan hasil uji One Way ANOVA didapatkan nilai signifikan 0.077. Dimana nilai signifikan tersebut lebih besar dari 0.05 , artinya $\mathrm{H} 0$ ditolak dan $\mathrm{H} 1$ diterima. $\mathrm{H} 1$ adalah tidak terdapat perbedaan yang signifikan antara return bulan Januari dengan rata-rata return bulan selain Januari, sehingga hasil penelitian January effect pada IHSG periode 2015-2019 adalah tidak terjadi January effect terhadap Indeks Harga Saham Gabungan di Bursa Efek Indonesia pada periode 2015-2019.

Di Indonesia, berdasarkan penelitian yang telah dilakukan hasil dalam penelitian ini sejalan dengan beberapa penelitian yang dilakukan. Penelitian dari Dwi Cahyaningdyah dan Dhany Kurniawan (2013) menyatakan bahwa tidak terjadi January 
effect di Bursa Efek Indonesia periode 2011-2012. Penelitian Fitri Aprilia \& Eka Ardhani (2014) menyatakan bahwa tidak terjadi January effect pada pasar modal Indonesia pada tahun 2012. Penelitian Sheryl Kadir dan Suramaya Suci (2014) menyatakan bahwa tidak terjadi fenomena January effect pada perusahaan yang terdaftar di LQ 45 di Bursa Efek Indonesia pada tahun 2010-2013. Penelitian yang dilakukan Mellina \& Kazia (2017) yang menyatakan tidak terdapat January effect pada sektor property, real estate, dan building construction di Bursa Efek Indonesia pada periode 2014-2016. Sejalan juga dengan penelitian yang dilakukan Darman (2018) yang menyatakan bahwa tidak terjadi fenomena January effect pada Indeks Harga Saham Gabungan di Bursa Efek Indonesia periode tahun 1997-2018.

Pasar efisien merupakan pasar dimana harga semua sekuritas yang diperdagangkan telah mencerminkan semua informasi yang tersedia (Tandelilin, 2017:224), saat pasar modal tidak sesuai dengan kriteria pasar efisien berarti terjadi anomali pasar. Salah satu bentuk anomali pasar menurut Gumanti (2011:343) adalah anomali musiman yang didalamnya termasuk January effect. Sementara itu, hasil dari penelitian ini menunjukkan tidak terjadi January effect pada IHSG di Bursa Efek Indonesia periode 2015-2019. Akan tetapi, January effect saja tidak bisa dijadikan acuan untuk menyatakan pasar modal tersebut merupakan pasar efisien, karena masih banyak anomali-anomali pasar lainnya yang dapat mempengaruhi pasar modal.

Hal ini dapat menjadi pertimbangan investor bahwa di Indonesia, fenomena January effect tidak terlalu bereaksi karena tidak ada perbedaan yang signifikan antara bulan Januari dan selain Januari dalam beberapa penelitian yang telah dilakukan. Investor dapat mempertimbangkan faktor-faktor lain yang dapat mempengaruhi indeks saham.

\section{KESIMPULAN DAN SARAN Kesimpulan}

Berdasarkan penelitian yang telah dilakukan dan berdasarkan hasil perhitungan menggunakan SPSS 25, didapatkan nilai signifikansinya 0,077 lebih besar dari 0,05. Hal tersebut berarti tidak terdapat perbedaan yang signifikan antara return bulan Januani dengan rata-rata return bulan selain Januari. Jadi, dapat disimpulkan bahwa anomali pasar musiman January effect tidak terjadi pada Indeks Harga Saham Gabungan di Bursa Efek Indonesia periode 2015-2019.

\section{Saran}

Untuk penelitian selanjutnya sebaiknya peneliti menambahkan variabelnya baik variabel dependent maupun variabel independent. Untuk investor, disarankan untuk tidak hanya mempertimbangkan January effect dalam pengambilan keputusan berinvestasi karena January effect tidak terlalu bereaksi di Indonesia. Banyak faktor lain yang dapat dipertimbangkan untuk mengambil keputusan investasi. 


\section{DAFTAR PUSTAKA}

Alteza, M. 2007. Efek Hari Perdagangan Terhadap Return Saham Suatu Telaah atas Anomali Pasar Efisien. Jurnal Ilmu Manajemen, Vol. 3, No. 1 Tahun 2007.

Audina, M. d. 2017. Analisis January Effect Pada Sektor Property, Real Estate, dan Building Construction di Bursa Efek Indonesia. Jurnal Riset Akuntansi dan Keuangan, Vol. 5, No. 1. ISSN 2338-1507.

Cahyaningdyah, D. d. 2013. Analisis January Effect Pada Saham Perusahaan LQ 45 di Bursa Efek Indonesia. Jurnal Maksipreneur, Vol. II, No. 2, hal 65-79.

Fitriyani, I. d. 2013. Analisis January Effect Pada Kelompok Saham Indeks LQ 45. EJurnal Akuntansi Universitas Udayana, Vol. 4, No. 2. 421-438. ISSN: 23028556.

Gumanti. 2011. Manajemen Investasi - Konsep, Teori, dan Aplikasi. Jakarta: Mitra Wacana Media.

I G A Made Agung Mas Andriani Pratiwi, d. 2018. Analisis January Effect Pada Perusahaan BUMN Di Bursa Efek Indonesia. Majalah Ilmiah Untab, Vol. 15, No.1.

Jogiyanto. 2013. Teori Portofolio dan Analisis Investasi. Yogyakarta: BPFEYogyakarta.

Kadir, S. d. 2014. Fenomena January Effect di Bursa Efek Indonesia (Studi Pada Perusahaan yang Terdaftar di LQ45 Periode 2010-2013). Jurnal Keuangan dan Bisnis, Vol. 12, No. 1.

Kamus Besar Bahasa Indonesia/Anomali. (t.thn.). Diambil kembali dari Kamus Besar Bahasa Indonesia: https://kbbi.web.id/anomali

Kevin, A. 2019. Masihkah January Effect Tersisa Bagi IHSG?. Diambil kembali dari Cnbcindonesia.com: https://www.cnbcindonesia.com/market/2019012115223217-51625/masihkah-january-effect-tersisa-bagi-ihsg

Sari, F. d. 2014. Analisis January Effect Di Pasar Modal Indonesia. E-Jurnal Akuntansi Universitas Udayana, Vol. 6, No. 2. 237-248. ISSN: 2302-8556.

Sugiyono. 2016. Metode Penelitian Kuantitatif, Kualitatif dan R\&D. Bandung: Alfabeta.

Sunariyah. 2011. Pengantar Pengetahuan Pasar Modal. Edisi Keenam. Yogyakarta: VPP AMP YKPN.

Tandelilin, E. 2017. Pasar Modal Manajemen Portofolio dan Investasi. Yogyakarta: Kanisius.

Yoga. 2010. Analisis Fenomerna January Effect Terhadap Return Pasar di Bursa Efek Indonesia. Riset Manajemen dan Akuntansi, Vol. 1, No. 2.

https://finance.yahoo.com

https://idx.co.id 